\title{
PERBEDAAN PENERAPAN MODEL PEMBELAJARAN TGT-PROBLEM POSING DAN JIGSAW TERHADAP MINAT DAN HASIL BELAJAR
}

\author{
Yosi Nur Kholisho \\ Program Studi Pendidikan Informatika, \\ Fakultas Keguruan dan Ilmu Pendidikan, Universitas Hamzanwadi \\ Email: yosink.peninfo@gmail.com
}

\begin{abstract}
Abstrak
Peroses pembelajaran yang menggunakan metode yang kurang menarik, akan berdampak terhadap hasil dan keaktifan, serta minat belajar mahasiswa. Oleh karena itu, perlu adanya model dan metode yang dapat menumbuhkan minat dan hasil belajar siswa, yakni model TGT dipadukan dengan problem posing. Penelitian ini bertujuan untuk mengetahui adanya pengaruh model TGT-Problem Posing terhadap hasil belajar dan minat belajar mahasiswa. Penelitian ini menggunakan rancangan pretest-posttest control group design. Populasi pada penelitian ini yaitu mahasiswa prodi pendidikan informatikan semester 3 terdiri dari 2 kelas. Sampel yang digunakan pada penelitian kelas A sebagai kelas eksperimen dan kelas B sebagai kelas kontrol dengan menggunakan teknik sampel jenuh. Variabel bebas pada penelitian ini adalah model TGT-Problem Posing dan jigsaw, dan variabel terikat adalah hasil belajar dan minat belajar mahasiswa. Hasil penelitian menunjukkan bahwa model pembelajaran TGT-Problem Posing pada kelas pada kelas eksperimen memiliki nilai rata-rata hasil belajar lebih tinggi di bandingkan dengan kelas kontrol 87,6 > 78,7. Terdapat perbedaan minat dan hasil belajar antara model pembelajaran TGT-problem posing dan model jigsaw.
\end{abstract}

Kata Kunci: Model TGT-Problem Posing, Model jigsaw, Minat Belajar, Hasil Belajar.

\begin{abstract}
Learning processes that use less attractive methods will have an impact on results and activeness, as well as student interest in learning. Therefore, the need for models and methods that can foster interest and student learning outcomes, namely the TGT model combined with problem posing. This study aims to determine the effect of the TGT-Problem Posing model on student learning outcomes and learning interest. This study uses a pretest-posttest control group design. The population in this study is the third semester informatics education study students consisting of 2 classes. Samples used in class $A$ research as experimental group and class $B$ as control group using saturated sample techniques. The independent variables in this study are the TGT-Problem Posing and jigsaw models, and the dependent variable is the learning outcomes and student learning interest. The results showed that the TGT-Problem Posing learning model in the class in the experimental class had an average value of learning outcomes higher compared to the control class 87.6> 78.7. There are differences in interests and learning outcomes between the TGT-problem posing learning model and the jigsaw model.
\end{abstract}

Keywords: TGT-Problem Posing Model, Jigsaw Model, Learning Interest, Learning Outcomes.

\section{PENDAHULUAN}

Kegiatan utama dalam proses pendidikan di sekolah adalah kegiatan belajar mengajar. Proses belajar yang ada merupakan penentu keberhasilan dalam mencapai tujuan pendidikan. Mahasiswa yang belajar diharapkan mengalami perubahan baik dalam bidang pengetahuan, keterampilan, nilai dan sikap. Perubahan tersebut dapat tercapai bila ditunjang berbagai macam faktor. Faktor yang dapat menghasilkan perubahan juga berpengaruh untuk meningkatkan hasil belajar dan minat belajar mahasiswa. Hasil belajar merupakan alat untuk mengukur sejauh mana mahasiswa menguasai materi yang telah diajarkan dosen. 
Upaya pembelajaran tersebut, terletak pada tanggung jawab dosen, bagaimana pembelajaran yang disampaikan dapat dipahami oleh anak didik secara benar. Dengan demikian, proses pembelajaran ditentukan sampai sejauh dosen dapat menggunakan metode dan model pembelajaran dengan baik. Model pembelajaran itu banyak macamnya, setiap model pembelajaran sangat ditentukan oleh tujuan pembelajaran, materi pembelajaran, karakteristik mahasiswa dan kemampuan dosen dalam mengelola proses pengajaran. Salah satu masalah yang dihadapi dosen untuk melaksanakan proses pembelajaran yang efektif dalam rangka meningkatkan hasil belajar adalah dengan meningkatkan minat belajar mahasiswa itu sendiri.

Beberapa cara untuk menumbuhkan minat belajar mahasiswa adalah melalui strategi pembelajaran dengan metode mengajar yang bervariasi, memberikan kesempatan pada mahasiswa untuk menyalurkan keinginan belajarnya, penggunaan media pembelajaran, dan sebagainya. Secara umum mahasiswa akan termotivasi untuk terlibat secara aktif dalam proses pembelajaran bila mahasiswa melihat situasi pembelajaran cendrung memuaskan dirinya sesuai dengan kebutuhan yang diharapakan.

Metode ceramah cendrung dipakai sebagai metode utama dalam pembelajaran hal tersebut bukan berarti tidak cocok untuk digunakan, akan tetapi penggunaan metode tersebut yang terkesan mendominasi menyebabkan mahasiswa cendrung merasa bosan, jenuh, dan menurunnya aktivitas dan minat belajar mahasiswa. Kondisi ini menjadi salah satu penyebab rendahnya penguasaan materi masing-masing kompetensi yang bisa berpengaruh terhadap hasil belajar mahasiswa.

Hal ini terjadi pada mata kuliah teori multimedia interaktif kelas A universitas hamzanwadi. Berdasarkan observasi yang dilihat saat awal pembelajaran ini menggunakan konsep pembelajaran terpusat pada dosen sedangkan mahasiswa menerima pembelajaran secara pasif.

Pola pembelajaran ceramah sangat kontra produktif dengan karakter kelas A yang sangat dinamis. Mahasiswa-siswi kelas A memiliki kelebihan berupa keterikatan individu yang sangat kuat, akan tetapi kelebihan tersebut menyebabkan kelemahan pada kelas ini yaitu konsentrasi pada pembelajaran sangat rendah dikarenakan mereka lebih senang ramai sendiri selama mengikuti pembelajaran. Rendahnya konsentrasi mahasiswa khususnya pembelajaran teori ini berakibat pada rendahnya minat mahasiswa, yang berdampak pada hasil belajar mahasiswa. Hal tersebut dibuktikan dengan nilai yang di dapat mahasiswa dalam tes kemampuan teori mahasiswa dengan nilai rata-rata yaitu 70 .

Agar dapat menciptakan situasi pembelajaran yang lebih bervariasi dan dapat menciptakan situasi pembelajaran maka perlu diterapkan model pembelajaran, misalnya model pembelajaran kooperatif. Belajar kooperatif didasarkan pada hubungan antara motivasi, hubungan interapersonal dan strategi pencapaian khusus. Oleh karena itu maka model pembelajaran kooperatif dapat dijadikan sebagai salah satu alternatif dalam pembelajaran untuk meningkatkan keaktifan mahasiswa, keterampilan berfikir, sikap positif terhadap materi pembelajaran, hasil belajar dan minat belajar.

Diantara model-model pembelajaran kooperatif adalah unik, dikarenakan pembelajaran ini merupakan suatu strategi tugas dan penghargaan yang berbeda dalam mengupayakan pembelajaran mahasiswa. Dimana struktur tugas tersebut menghendaki mahasiswa untuk bekerja bersama dalam kelompok-kelompok kecil.

Salah satu model pembelajaran kooperatif yaitu tipe TGT dipadukan dengan problem posing pembelajaran ini melibatkan mahasiswa dalam setiap pembelajaran. Mahasiswa terdiri 
dari kelompok heterogen yang terdiri dari 3-4 anak. Mahasiswa harus memecahkan masalah yang diberikan oleh dosen dan mempresentasikan hasil pada teman kelompok lain.

Melalui model pembelajaran TGT diharapkan dapat memberikan solusi dan suasana baru yang menarik dalam pengajaran sehingga memberikan konsep baru. Pembelajaran TGT membawa konsep pemahaman inovasi, dan menekankan keaktifan mahasiswa sehingga diharapkan dapat meningkatkan minat belajar mahasiswa dan hasil belajar dapat ditingkatkan dengan adanya model pembelajaran TGT.

Salah satu faktor internal yang sangat berpengaruh terhadap hasil belajar adalah minat. Menurut Slameto (2010:57) minat adalah kecendrungan yang tetap untuk memperhatikan dan mengenang beberapa kegiatan, yaitu kegiatan yang diminati seseorang akan diperhatikan terus-menerus dan disertai dengan rasa senang. Suatu minat dapat di eksperikan melalui suatu pernyataan yang menunjukkan bahwa mahasiswa lebih menyukai suatu hal daripada yang lainnya, dapat pula diminifestasikan melalui partisipasi dalam suatu aktivitas. Mahasiswa yang memiliki niat terhadap subjek tertentu cendrung untuk memberikan perhatian yang lebih besar terhadap subjek tersebut.

Penelitian ini bertujuan untuk: 1. mengetahui apakah hasil belajar mahasiswa dengan penerapan metode pembelajaran TGT-Problem Posing dibandingkan dengan pembelajaran jigsaw; 2. mengetahui apakah minat belajar mahasiswa dengan penerapan metode pembelajaran TGT-Problem Posing dibandingkan dengan pembelajaran jigsaw.

\section{METODE}

Dalam penelitian ini digunakan jenis rancangan Quasy Experiment (semi eksperimen) dengan model Pretest-Postest Nonequivalent Control Group Design. Desain ini terdiri dari kelompok eksperimen, dan kelompok kontrol. Sebelum perlakuan dilakukan pretes terlebih dahulu untuk memeriksa kesamaan kemampuan awal dari kelompok-kelompok penelitian, dan diukur sekali lagi setelah perlakuan dilaksanakan.

Populasi dari penelitian ini adalah Mahasiswa prodi pendidikan informatika semester 3 terdiri dari 2 kelas. Sampel penelitian dengan menggunakan sampel jenuh artinya seluruh populasi sebagai sampel terdiri dari 2 kelas tersebut yakni 1 kelas sebagai kelas kontrol pada kelas A dan 1 kelas sebagai kelas eksperimen pada kelas B.

Instrumen yang digunakan yaitu instrumen perlakuan yaitu RPS, bahan ajar dan instrumen pengukuran yaitu tes, tugas, angket. Pengumpulan data yaitu untuk data kemampuan awal mahasiswa diperoleh dari nilai pretest kemudian dianalisis uji kesamaaan dua rata-rata dan data hasil belajar diperoleh dari hasil posstest kemudian dianalisis uji beda terhadap model pembelajaran yang diterapkan. Sehingga pada penelitian ini akan diketahui perbedaan hasil belajar mahasiswa kelas eksperimen dan kelas kontrol. Uji hipotesis membuktikan: 1) ada perbedaan hasil belajar mahasiswa dengan penerapan metode pembelajaran TGT-Problem Posing dibandingkan dengan pembelajaran jigsaw; 2) ada perbedaan minat belajar mahasiswa dengan penerapan metode pembelajaran TGT-Problem Posing dibandingkan dengan pembelajaran jigsaw..

\section{HASIL DAN PEMBAHASAN}

\section{Hasil Penelitian}

\section{Data Kemampuan Awal Mahasiswa}

Data kemampuan awal mahasiswa merupakan kemampuan mahasiswa sebelum diberi perlakuan yang diperoleh dari nilai hasil pretest. Deskripsi data kemampuan awal mahasiswa ditunjukkan pada Tabel 1. 
Tabel 1 Data Kemampuan Awal Mahasiswa

\begin{tabular}{lll}
\hline Parameter & Kelas Kontrol & Kelas Eksperimen \\
\hline $\mathbf{N}$ & 29 & 30 \\
Nilai Tertinggi & 64 & 60 \\
Nilai Terendah & 36 & 36 \\
Rata-rata & 49.24 & 47.6 \\
\hline
\end{tabular}

Setelah dilakukan uji prasyarat analisis yang meliputi uji normalitas dan uji homogenitas, didapatkan kesimpulan bahwa nilai kemampuan awal mahasiswa kedua kelas berdistribusi normal dan kedua kelas mempunyai tingkat varians yang sama (homogen). Dari hasil uji kesamaan dua rata-rata diperoleh kesimpulan bahwa tidak ada perbedaan kemampuan awal mahasiswa antara kelas kontrol dan kelas eksperimen.

\section{Data Hasil Belajar Mahasiswa}

Data hasil belajar mahasiswa diperoleh dari akumulasi nilai posttest, tugas, dan afektif. Rata-rata nilai posttest kelas kontrol dan kelas eksperimen dapat dilihat pada Tabel 2.

Tabel 2 Data Hasil Belajar

\begin{tabular}{lll}
\hline \multicolumn{1}{c}{ Nilai } & Kelas Kontrol & Kelas Eksperimen \\
\hline Rata-rata & 78.7 & 87.6 \\
Nilai terendah & 73.2 & 79.2 \\
Nilai Tertinggi & 86.8 & 92.5 \\
\hline
\end{tabular}

Setelah dilakukan uji prasyarat analisis yang meliputi uji normalitas dan homogenitas, didapatkan kesimpulan bahwa nilai hasil belajar mahasiswa kedua kelas berdistribusi normal dan homogen.

\section{Uji Hipotesis}

Hasil uji hipotesis nilai hasil belajar mahasiswa antara kelas kontrol dan kelas eksperimen ditunjukkan pada Tabel 3 dan Tabel 4 untuk minat.

Tabel 3 Hasil Uji Hipotesis pada Hasil Belajar

\begin{tabular}{|c|c|c|c|c|c|c|c|c|c|c|c|}
\hline & & $\begin{array}{l}\text { Leye } \\
\text { Test } \\
\text { Equal } \\
\text { Variar }\end{array}$ & $\begin{array}{l}\text { ne's } \\
\text { for } \\
\text { lity of } \\
\text { nces }\end{array}$ & \multicolumn{7}{|c|}{ t-test for Equality of Means } & \\
\hline & & \multirow[b]{2}{*}{$\mathrm{F}$} & \multirow[b]{2}{*}{ Sig. } & \multirow[b]{2}{*}{$\mathrm{t}$} & \multirow[b]{2}{*}{ df. } & \multirow{2}{*}{$\begin{array}{l}\text { Sig. (2- } \\
\text { tailed) }\end{array}$} & \multirow{2}{*}{$\begin{array}{c}\text { Mean } \\
\text { Difference }\end{array}$} & \multirow{2}{*}{$\begin{array}{l}\text { Std. Error } \\
\text { Difference }\end{array}$} & \multicolumn{3}{|c|}{$\begin{array}{c}95 \% \text { Confiderice } \\
\text { Interval of the } \\
\text { Difference }\end{array}$} \\
\hline & & & & & & & & & Lower & Upp & \\
\hline \multirow[t]{2}{*}{$\begin{array}{l}\text { nilai } \\
\text { sisya }\end{array}$} & $\begin{array}{l}\text { Equal } \\
\text { variances } \\
\text { assumed }\end{array}$ & 0.001 & .979 & 10.356 & 57 & .000 & 8.86253 & .85580 & 7.1488 & 10.57 & 625 \\
\hline & $\begin{array}{l}\text { Equal } \\
\text { variances not } \\
\text { assumed }\end{array}$ & & & 10.348 & 56.64 & .000 & 8.86253 & .85648 & 7.1472 & 10.57 & 784 \\
\hline
\end{tabular}

Nilai Sig. $(2$-tailed $)=0,000$ sehingga nilai Sig. $(2$-tailed $)<0,05$ yaitu $(0,000<0,05)$. Jika dilihat dari nilai $\mathrm{t}_{\text {hitung }}=10.356$ dan $\mathrm{t}_{\text {tabel }}$ dari $\mathrm{df}=59-2=57$ dengan $\alpha=0,05$ (untuk uji dua pihak) diperoleh nilai $t_{\text {tabel }}=2.002$ sehingga $t_{\text {hitung }}>t_{\text {tabel }}$ yaitu $(10.356>2.002)$. Kesimpulannya bahwa Ho ditolak yaitu terdapat perbedaan hasil belajar antara mahasiswa 
yang mengikuti model pembelajaran TGT-Problem Posing dengan mahasiswa yang mengikuti model jigsaw mata kuliah teori multimedia interaktif.

Tabel 4 Hasil Uji Hipotesis pada Minat Belajar

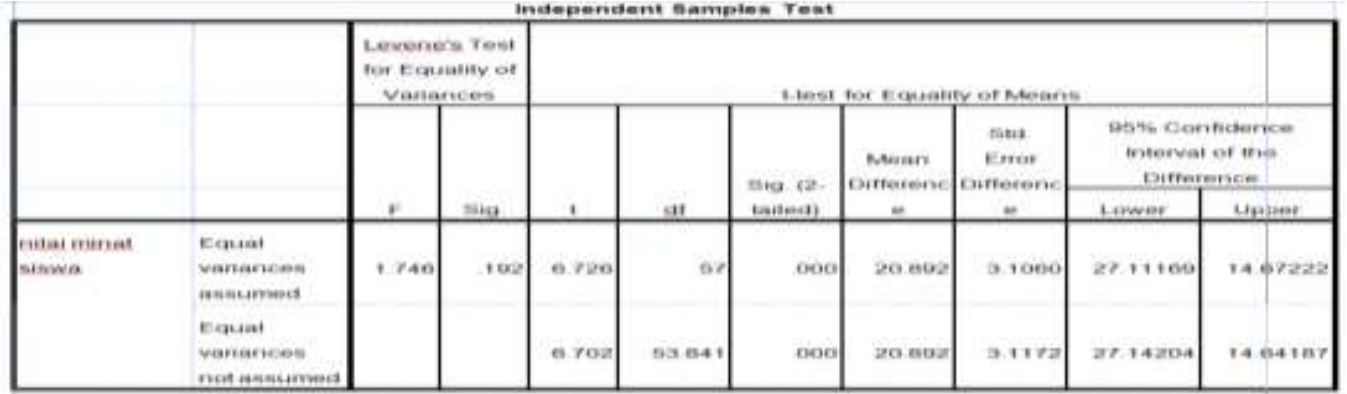

Sig.(2-tailed $)=0,000$ sehingga nilai Sig. $(2$-tailed $)<0,05$ yaitu $(0,000<0,05)$. Jika dilihat dari nilai $t_{\text {hitung }}=6.726$ dan $t_{\text {tabel }}$ dari $\mathrm{df}=59-2=57$ dengan $\alpha=0,05$ (untuk uji dua pihak) diperoleh nilai $t_{\text {tabel }}=2.002$ sehingga $t_{\text {hitung }}>t_{\text {tabel }}$ yaitu $(6.726>2.002)$. Kesimpulannya bahwa Ho ditolak yaitu terdapat perbedaan minat belajar antara mahasiswa yang mengikuti model pembelajaran TGT-Problem Posing dengan mahasiswa yang mengikuti model jigsaw mata kuliah teori multimedia interaktif.

\section{Pembahasan}

\section{Perbedaan Hasil Belajar Mahasiswa Kelas Kontrol dan Kelas Eksperimen}

Hasil belajar mahasiswa kelas eksperimen dan kontrol diperoleh bahwa ada perbedaan hasil belajar mahasiswa. Dalam hal ini adanya perbedaan hasil belajar mahasiswa kelas kontrol dan kelas eksperimen hanya disebabkan oleh perlakuan yang terjadi dalam penelitian yaitu dengan menggunakan model pembelajaran TGT-Problem Posing untuk kelas eksperimen sedangkan untuk kelas kontrol menggunakan model jigsaw menunjukkan bahwa hasil belajar kelas eksperimen nilai tertinggi adalah 92.5 dan nilai terendah adalah 79.2 dengan nilai rata-rata adalah 87.6 dan standar deviasi adalah 3.23, sedangkan nilai tertinggi pada kelas kontrol adalah 86.8 dan nilai terendah adalah 73.2 dengan nilai rata-rata adalah 78,7 dan standar deviasi yaitu 3.36.

\section{Perbedaan Minat Belajar Mahasiswa Kelas Kontrol dan Kelas Eksperimen}

Dari hasil analisis pada kelas kontrol dan eksperimen didapatkan bahwa terdapat perbedaan minat belajar antara kelas kontrol dan kelas eksperimen yang terdapat pada tabel 4.12, hal tersebut dibuktikan dengan dari nilai $t_{\text {hitung }}=6.726$ dan $t_{\text {tabel }}$ dari $\mathrm{df}=59-2=57$ dengan $\alpha=0,05$ (untuk uji dua pihak) diperoleh nilai $t_{\text {tabel }}=2.002$ sehingga $t_{\text {hitung }}>t_{\text {tabel }}$ yaitu $(6.726>2.002)$.

Angket minat terdiri dari 4 aspek yang telah diukur yaitu ketertarikan terhadap media, perhatian dan keinginan, kebutuhan, kesenangan dan kemauan. Menggunakan skala Likers yaitu $\mathrm{SS}=$ sangat setuju dengan nilai $5, \mathrm{~S}=$ setuju dengan nilai $4, \mathrm{~N}=$ netral dengan nilai 3 , TS = tidak setuju dengan nilai 2 , dan STS = sangat tidak setuju dengan nilai 1 . Sedangkan dengan skor negatif skor pilihan jawabannya adalah SS : 1, S : 2, N : 3, TS : 4, STS : 5 .

Angket minat ini diberikan setelah di beri perlakuan model TGT-Problem Posing untuk kelas eksperimen dan untuk kelas kontrol dengan model jigsaw setelah diberikan posttest pada mahasiswa. Angket digunakan untuk mengetahui minat mahasiswa terhadap proses pembelajaran. Angket ini terdiri dari 25 pertanyaan. Terdiri dari pertanyaan negatif dan pertanyaan positif. 


\section{Penerapan Model Pembelajaran TGT-Problem Posing Terhadap Hasil Belajar}

Berdasarkan nilai rata-rata hasil belajar kelas eksperimen dan kelas kontrol yaitu 87.6 dan 78.7 dapat diketahui bahwa nilai hasil belajar kelas eksperimen lebih tinggi dibandingkan dengan dengan kelas kontrol. Hal ini di karenakan model TGT-ProblemPosing memberikan kesempatan pada mahasiswa untuk langsung aktif dalam proses pembelajaran. Mahasiswa di tuntut untuk lebih banyak mencari informasi sendiri di bandingkan dengan informasi yang di berikan oleh dosen, sehingga mahasiswa dapat mengembangkan potensi dan daya pikir yang ia miliki dengan berusaha mencari jawabab dari permasalahan yang ada dengan saling tukar pikiran atau pendapat dengan anggota kelompoknya. Model TGT merupakan metode pembelajaran yang menekankan pada kekompakan dalam kelompok. Metode ini menuntut para mahasiswa untuk memiliki kemampuan yang baik dalam berkomunikasi maupun dalam keterampilan kelompok.

\section{SIMPULAN}

Berdasarkan hasil penelitian dan analisis data yang telah dilakukan maka simpulan pada penelitian ini adalah (1) Terdapat perbedaan antara hasil belajar mahasiswa yang mengikuti model pembelajaran TGT-Problem Posing dengan yang mengikuti model jigsaw pada mata kuliah multimedia interaktif semester $3(\rho<0.05)$, (2) Terdapat perbedaan yang signifikan antara minat belajar mahasiswa yang mengikuti model pembelajaran TGT-Problem Posing dengan yang mengikuti model jigsaw pada mata kuliah multimedia interaktif semester 3 $(\rho<0.05)$.

\section{REFERENSI}

Arikunto, Suharsimi. (2010). Proses Penelitian Suatu Pendekatan Praktis. Jakarta: Rineka Cipta.

Dimyati \& Mudjiono. (2006). Belajar dan Pembelajaran. Jakarta: Rineka Cipta.

Nisfianoor, Muhammad. (2009). Pendekatan Statistik Modern untuk Ilmu Sosial. Jakarta: Salemba Humanika.

Riduwan. (2004). Belajar Mudah, Penelitian untuk Dosen-Karyawan dan Peneliti Muda. Bandung: Alfabeta

Slameto. (2010). Belajar \& Faktor-faktor yang Mempengaruhi. Jakarta: Rineka Cipta

Sardiman. (2005). Interaksi dan Motivasi belajar Mengajar. Bandung : Raja Grafindo

Slavin, Robert E. (2008). Cooperative Learning. Bandung: Nusa Media

Sugiyono. (2010). Memahami Penelitian Kualitatif. Bandung: Alfabeta

Sugiyono. (2011). Statistika untuk Penelitian. Bandung: Alfabeta 